\title{
Træning i etiske dilemmaer - En ny tilgang til at forebygge doping?
}

\section{Anne-Marie Elbe ${ }^{1} \&$ Ralf Brand ${ }^{2}$}

${ }^{1}$ Leipzig Universitet, Germany, ${ }^{2}$ Postdam Universitet, Germany

\section{Resumé}

Mange moralske og etiske værdier er tillagt sport fordi det er regelbaseret (e.g., Anderson \& Crutchley, 1990). Som en konsekvens af dette bliver sport ofte set som en slags kropsliggørelse af etisk opførsel (McFee, 1998). Denne idealistiske tilskrivelse af moralsk mening til sport hedder sport ethos (Kuchler, 1969). Ofte bliver termerne "moral" og "etik" brugt som synonymer da de begge beskriver handling som tolkes som enten "rigtig" eller "forkert". Moral betegner en persons principper og bliver derved fuldt af individet selv. Et individs moralske koder er oftest stabilt og konsistent på tværs af kontekster, men kan ændres hvis en person har en radikal ændring i personlige overbevisninger og/eller værdier. Etik er eksterne standarder, givet af institutioner, grupper eller en kultur som individet hører til. Etik er meget konsistent i en given kontekst, men kan variere meget fra kontekst til kontekst. I dag bruges etik ofte om systematisk undersøgelse af moral. I denne artikel vil vi diskutere moralsk udvikling i sport, relevansen af moralsk ræsonnement for anti-doping forbyggelse, og vi vil præsentere nye resultater fra et træningsprogram målrettet at øge unge atleters moralske ræsonnement for at forebygge doping.

Nøgleord: Etik, moral, etisk træning, træning af moral, doping

Mange moralske og etiske værdier bliver tilskrevet sport, fordi den er regel-baseret (f.eks., Alderson \& Crutchley, 1990). Derfor bliver sport oftest anset som kropsliggørelsen af etisk opførsel (McFee, 1998). Denne idealistiske tilskrivning af moralsk betydning til sport kaldes sportens etos (Kuchler, 1969). I mange tilfælde bliver begreberne moral og etik brugt i flæng, fordi de begge henviser til handlinger, der vurderes som værende enten "rigtige" eller "forkerte". Moral som begreb er de personlige principper, der er skabt og som opretholdes af individer selv. En persons moralkodeks er normalt stabilt og ensartet på tværs af kontekster, men kan ændre sig, hvis individet har en radikal ændring i sine personlige overbevisninger og/eller værdier. Etik er eksterne krav, fremsat af institutioner, grupper eller en kultur som individet tilhører. Etik er meget konsistent indenfor en bestemt kontekst, men kan variere meget imellem kontekster. I dag refererer etik ofte til systematiske undersøgelser af moral. I dette kapitel vil vi diskutere den moralske udvikling i sporten, relevansen af moralsk begrundelse for anti-doping forebyggelse, og vi vil præsentere nye resultater fra et træningsprogram, der har til formål at øge unge atleters moralske ræsonnement for at forebygge doping.

Etiske Spørgsmål i Sport

Sportens domæne er tæt forbundet med etiske spørgsmål, fordi sportslig adfærd oftest er kendetegnet ved interaktion imellem individer (McFee, 1998). Imidlertid kan en meningsfuld diskussion af moral og etik i sport kun finde sted ved omhyggeligt at analysere begrebet sport (Steenbergen \& Tamboer, 1998). Tanken om ubegrænsede præstationer i sport rejser mange etiske og moralske spørgsmål. Som McFee (1998, s. 5) pointerer, "etiske spørgsmål opstår ... fra sportens natur." Franke (1978) beskriver sport som "en verden i sig selv" på grund af to modsatrettede principper: på den ene side skal atleter besejre deres modstandere, mens de på anden side skal udvise fairness. Franke (1988) fremsætter det som et "system af iboende spænding" (citeret i Steenbergen \& Tamboer, 1998, s. 36). Spørgsmålet er, i hvilken grad en balance mellem disse modsatrettede principper kan findes i moderne sport.

Begreber som fairplay, at spille efter reglerne og sportspersonship har været forbundet med moral i sport, og kan opfattes som beskrivelser af sportslig adfærd, der vejleder atleter $\mathrm{i}$ deres bestræbelser på at håndtere disse iboende spændinger i sport. Begrebet sportspersonship refererer bredt til en sportsudøvers forståelse af og respekt for regler, ritualer og traditioner i sport, samt evnen til at skelne mellem god og dårlig praksis i sport (Siedentop, Hastie, \& van der Mars, 2004). Ifølge Ommundsen, Roberts, Lemyre og Treasure (2003) er sportspersonship eksempelvis, når atleter undlader at drage nytte af en urimelig fordel i forhold til en modstander, når atleter spiller efter reglerne på en fair måde, og når de gør deres bedste.

I betragtning af de forventninger, der er forbundet med denne opfattelse af sportspersonship, er det ikke overraskende, at forekomsten af uetisk opførsel vejer tungt, da det kan anskues som et angreb på sportens inderste værdier. Etiske problemstillinger i forbindelse med sport er eksempelvis de af lighed, adgang til sport, afvigende subkulturer samt adfærd eller udnyttelse (Morgan, 2007). I sport er den etiske diskurs forbundet med sportsfilosofien og refererer til undersøgelsen af etisk problematisk adfærd, personer eller politikker. Doping indenfor sport, der kan kategoriseres som en afvigende 


\section{Sport and Exercise Psychology}

adfærd, er et emne, som således har fået øget interesse fra sportsfilosofien. Doping kan opfattes som et fænomen, der i høj grad er i konflikt med sportens værdier, da det at anvende forbudte, præstationsfremmende præparater eller at bruge forbudte metoder til at vinde, eller at besejre en modstander går imod reglen om fairness og derved skaber ulige betingelser. Sportsetikken opfatter det at præsentere problem-fokuserede løsninger til dopingdiskussionen, som sin mest presserende opgave (Pawlenka, 2004). Etiske overvejelser om brugen af præstationsfremmende præparater i sport er et meget omdiskuteret emne (se eksempelvis Bockrath \& Franke 1995; Hemphill, 2009; Volkwein, 1995). Schneider og Butcher (2000) kategoriserer argumenter om doping under fire overskrifter: snyd og urimelighed, skade, perversion af sport, samt unaturlighed og umenneskeliggørelse.

Udvikling af moralske handlinger i sport

Taget i betragtning, at etiske spørgsmål i sport er tæt relateret til forbruget af ulovlige præstationsfremmende præparater, opstår spørgsmålet, hvordan en sportsudøvers opfattelse af, hvad der er rigtigt og forkert i sport udvikler sig. Sportens etos alene garanterer ikke, at atleter vil vise moralsk adfærd. En klar sammenhæng mellem sportsdeltagelse og den moralske udvikling har kun begrænset empirisk støtte (Kavussanu \& Ntoumanis, 2003). Generelt gør sporten ikke automatisk individer til moralske personer. Tværtimod synes uetisk adfærd at være endnu mere accepteret i sport end i dagligdagen (Bredemeier \& Shields, 1984). For eksempel, viste Long, Pantaléon, Bruant og d'Arripe-Longueville (2006), at atleter anskuer regelovertrædelser som en legitim taktisk metode. Atleter bruger ønsket om at vinde som en mulig forklaring på denne opførsel og anser "beskedne" former for regelovertrædelser som en del af spillet (se Pilz, 1995). Som konsekvens heraf vil sport kun til en vis grad bidrage til den moralske udvikling af børn og unge voksne. I almindelighed kan etisk og moralsk opførsel kun tillæres i en mere generel samfundsmæssig sammenhæng. Sport repræsenterer kun en sub-kontekst, hvor læring omkring og accept af etiske værdier og principper kan faciliteres. Det er derfor vigtigt at forstå, hvordan moralske ræsonnementer hovedsageligt udvikler sig hos individer, for at kunne forstå hvordan moral udvikler sig i forbindelse med sport.

Udvikling af moral

Ifølge Piaget (1932) opstår den moralske udvikling sideløbende med et barns generelle kognitive udvikling, som udvikler sig med alderen. Børn udvikler sig fra en amoralsk fase til en fase af simpel moralsk realisme. I denne fase tror børn at alt, hvad der ikke straffes er tilladt, og alt det der straffes er forbudt. I den følgende fase, den såkaldte heteronome fase af moral ( $i$ alderen fra fire til otte år), er børns moralske overbevisninger baseret på forholdet mellem begrænsninger. Moral anskues som noget, der er fastlagt af andre. Alt det andre accepterer er tilladt, og det de ikke accepterer, er ikke tilladt. Den sidste fase, den autonome moralske fase (cirka efter niårsalderen), opstår, når moral opfattes som noget, der bygger på relationer til andre og noget, der kan forhandles gennem gensidige aftaler med andre.

Lawrence Kohlberg byggede videre på Piagets teori, men i modsætning til Piagets teori, identificerede Kohlberg (1964) seks udviklingsfaser, der er opdelt i tre niveauer. Hver af udviklingsfaserne giver mulighed for en mere sofistikeret moralsk adfærd end den foregående. Tempoet, hvori et individ stiger i disse faser eller om faserne (især højere) overhovedet opnås, er forskelligt fra individ til individ. I modsætning til Piaget beskriver Kohlberg altså den moralske udvikling som noget meget individuelt og ikke som noget, der automatisk udvikler sig i overensstemmelse med den generelle kognitive udvikling. Kohlbergs tre niveauer er præ-konventionel, konventionel and post-konventionel moral. De to faser på det prækonventionelle niveau fokuserer på lydighed og straf samt på individualisme og udveksling. I disse faser, som hovedsageligt vedrører børn, anskues regler som faste absolutter og at adlyde dem er en måde at undgå straf. I anden fase af det præ-konventionelle niveau er handlinger bedømt på, hvordan de tjener individuelle behov. På det andet niveau (det konventionelle moralske niveau) spiller andre personer og samfundet en vigtigere rolle. Individet fokuserer mere på at leve op til samfundets forventninger, at gøre sin pligt og at respektere autoriteterne. Fokus er på at følge reglerne for at opretholde lov og orden. På det sidste niveau, post-konventionel moral, anerkendes forskellige værdier, overbevisninger og meninger. I den afsluttende fase, er moralsk ræsonnement baseret på abstraktion ved anvendelse af universelle etiske principper. Etiske dilemmaer

Kohlberg anvender disse forskellige stadier som grundlag for at vurdere en persons niveau af moralsk ræsonnement. Hans metode tager udgangspunkt $i$ at lade individer diskutere etiske dilemmaer, hvor den mest berømte er "Heinz dilemma". Dette dilemma beskriver en situation, hvor en mand overvejer at stjæle dyr kræftmedicin for at redde sin kones liv. Han føler sig tvunget til at stjæle medicinen, fordi han ikke har de finansielle ressourcer til at købe den; alt imens hans kones tid er ved at løbe ud. Kohlberg benytter individets niveau af raffinement $i$ diskussionen af situationen til at bestemme, i hvilken af de seks særskilte faser en person tilhører. Med udgangspunkt i dette rationale i henhold til diskussionen af etiske dilemmaer, brugte Blatt (1969) og Lind (2009) denne metode, ikke blot for at kategorisere en persons niveau af moralsk udvikling, men også som et redskab til at fremme udviklingen af moralske færdigheder. Blatt (1969) fokuserede på "for og imod" dialogen (jf. Blatt \& Kohlberg, 1975). Årtier senere udviklede Lind (2009) en omfattende metode til at træne moralske evner. Effektiviteten ved dilemmadrøftelser for at forbedre moralske færdigheder er, for eksempel, blevet vist i erhvervslivet (f.eks., Lerkiatbundit, Utaipan, Laohawiriyanon, \& Teo, 2006).

Tidligere er dilemmateknikken også blevet anvendt i flere undersøgelser til at bestemme atleters moralske opfattelser. Det mest anvendte dilemma, i forhold til doping i sport, er Goldman dilemmaet. Det rejser spørgsmålet om, hvorvidt atleter ville tage et dopingmiddel, der ville garantere dem en olympisk medalje, men som samtidig ville resultere i deres død indenfor fem år (Connor, Mazanov, \& Woolf, 2013; Goldman, Bush, \& Klatz, 1984). Goldman dilemmaet blev anvendt for at undersøge atleters moralske opfattelse, men dilemmaet blev ikke anvendt på en måde, der søgte at fremme moralske færdigheder, som foreslået af Lind, for eksempel, eller som tidligere anvendt i erhvervslivet.

Promovering af etisk opførsel i forhold til doping.

Tidligere har den mest almindelige procedure, for at sikre at atleter overholder anti-doping reglerne, været regelmæssig dopingkontrol og straf af positive tests (opdagelse [detection] og afskrækkelse[deterrence]tilgangen, Houlihan, 2002). I mere end 10 år har organisationsstrukturer og standardprocedurer eksisteret for at sikre overensstemmelse med anti-doping regulativer som beskrevet i det internationale antidopingagentursreglement (WADA, 2009). Den underliggende antagelse er, at opdagelse og afskrækkelses tilgangen måske indirekte vil fremme atleters etiske opførsel.

Der er dog flere indikatorer, der taler imod praksissen bag opdagelse og afskrækkelse politikken. Denne praksis 


\section{Sport and Exercise Psychology}

er meget dyr, hvilket kan tilskrives det store antal af kontroller, der skal foretages samt den konstante udvikling af nye teknologier for at tage højde for nyligt udviklede dopingpræparater og metoder (Trout \& Kazlauskas, 2004). Endvidere er der nogle af de forbudte præparater, som endnu ikke kan testes for. Haugen (2004) argumenterer for, at for at gøre testning mere effektiv som en afskrækkelse metode, bør volumen af udførte tests eller af pålagte sanktioner øges betydeligt - potentielt skal det øges til et niveau, som gør det umuligt at gennemføre i praksis. Desuden antyder Overbye, Elbe, Knudsen og Pfister's (2014) undersøgelse, at sociale og selvvalgte (moralske) sanktioner har en mere afskrækkende effekt end den juridiske udelukkelse fra sport af danske eliteatleter.

Derfor har nyere tilgange til at bekæmpe doping i sport haft fokus på den uddannelsesbaserede tilgang. Indenfor denne tilgang bruges læringsværktøjer til at uddanne unge atleter, så de afholder sig fra at bruge præstationsfremmende præparater. Den mest almene uddannelsesbaserede tilgang har været den vidensbaserede tilgang (Hanson, 2009; Backhouse, McKenna \& Patterson, 2009). Antagelsen bag denne tilgang er, at hvis der er nok information omkring risici og fare ved den afvigende opførsel, så vil modstridende intentioner formes og den respektive opførsel vil aftage (Ajzen, 1991). I forhold til feltet anti-doping, betyder dette, at information omkring hvad doping er, at det er forbudt og at det er usundt, præsenteres for atleterne. Mange forebyggende interventioner virker til hovedsageligt at have fokus på at videreformidle nødvendig viden, som så forventes at medføre forandringer $\mathrm{i}$ indstillingen til doping og/eller mindske intentionerne om at tage doping (f.eks., Goldberg et al., 2000; Laure \& Lecerf, 2002). Den underliggende antagelse er, ligesom i opdagelse og afskrækkelsetilgangen, at udbredelse af viden indirekte vil kunne forbedre atleters etiske opførsel. Dog er disse og andre forebyggende dopinginterventioner, som kun er påvist at være delvist effektive (for et review, se Backhouse et al., 2009), kritiseret af flere årsager. Disse interventioner har vist sig at øge viden omkring doping, men empiriske undersøgelser har i overvældende grad illustreret at simpel vidensoverførsel ikke er nok (Laure \& Lecerf, 1999; 2002). Hanson (2009) påpeger, at det er utilstrækkeligt udelukkende at fokusere på undervisning, hvis man ønsker at ændre en given adfærd. Traditionelle måder at oplyse omkring de negative effekter ved doping, producerer viden, som er svær at anvende, når den virkelige situation opstår. Endvidere er beslutningen om at tage doping til tider karakteriseret ved spontane og begrænset evaluerede kognitive processer (Petroczi, Aidman, \& Nepusz, 2008). Størstedelen af de forebyggende interventioner kan således følge en suboptimal tilgang, når de antager at doping altid er en forudset og rationel eller endda "planlagt" handling (Ajzen, 1991). Abstrakt viden, for eksempel omhandlende sundhedsrisici ved doping eller etiske advarsler, kan måske danne et grundlag for en atlets beslutning, men vil alene ikke være tilstrækkeligt til at forhindre doping.

Ifølge Backhouse et al. (2009), skal den optimale forebyggende intervention, efter moderne standarder, være en blanding af at videreformidle viden, kompetencer og tilstrækkelig affektion (værdier, selvbevidsthed og selvværd). Singler og Treutlein (2010) definerer disse kompetencer som observerende, reflekterende, besluttende og handlende. De pointerer yderligere, at en god forebyggende intervention hverken bør indtage den højeste moralske position overfor deltagerne eller forsøge at overbevise dem ved at indgyde frygt. I stedet bør en sådan intervention styrke de eksisterende ressourcer og kompetencer, som den unge voksne allerede besidder
(Singler, 2011). Louveau, Augustini, Duret, Irlinger, og Marcellini (1995) foreslår at inkludere diskussionen af modargumenter $\mathrm{i}$ en forebyggende intervention for at fremme udviklingen af ens egen holdning. Hanson (2009) foreslår, at interventioner burde designes på en sådan måde, at de vil sætte spørgsmålstegn ved validiteten af atleters eksisterende overbevisninger. Forebyggende interventioner bør derfor have som målsætning at forandre kognitive strukturer for at inkorporere interpersonelle kontrolprocesser, som er dybt indlejret i ens egen subjektive natur.

Træning af etisk beslutningstagen i sport.

Det er her vores tilgang til at diskutere etiske dilemmaer kommer i spil. Respektive interventioner skal flytte fokus fra ren vidensopbygning og i stedet fokusere på de trænedes evner til at træffe etiske beslutninger i forhold til konkrete situationer relateret til dopingadfærd. Vores metode anvender dilemmadiskussionsteknikken som teoretisk grundlag. Baseret på Blatt, Kohlberg og Linds foreslåede koncepter, udviklede vi et træningsprogram rettet mod forebyggelse af doping i sport, som en del af et WADA finansieret samfundsvidenskabeligt forskningsprojekt (Elbe \& Brand, 2013).

Grundlaget for dette etisk beslutningstagen træningsprogram er dilemmateknikken, hvor deltagere skal tackle forskellige sportsspecifikke dilemmasituationer relateret til doping. Atleterne bliver konfronteret med specifikke etiske dilemmasituationer, som de skal reflektere over og finde en løsning på. I deen er, at der ikke skal være fokus på at lære regler, men i stedet på en aktiv involvering af deltagerene ved at lade dem rekonstruere svære situationer, der kræver, at de tager egne, men subjektivt velbegrundede beslutninger. Det forventes, at denne metode fremmer udviklingen af en personlig, værdibaseret overbevisning omkring doping. Ved at følge Barrys (1979) analytiske ramme for etisk beslutningstagen, bliver vores deltagere konfronteret med argumenter for og imod doping (og/eller er nødt til at skabe deres egne), der har fokus på specifikke etiske principper forbundet til sportsrelaterede (sub-) kulturelt bestemte regler eller normer (for et review, se Gandz \& Hayes, 1988).

Empirisk Undersøgelse af et Anti-Doping Etisk Beslutningstagen Program

Elbe og Brands undersøgelse $(2013 ; 2016)$ havde til formål at klarlægge og evaluere effektiviteten af et træningsprogram, der skulle fremme atleters kompetencer i forhold til etisk anti-doping beslutningstagen. Den underliggende antagelse var, at den kognitive vurderingsproces og evaluering af understøttende argumenter og modargumenter kræver særlige mentale kompetencer og evner, der måske ikke er intuitivt tilgængelige. Moralske færdigheder kræver en intensiv lærings- og træningsproces (cf. Wright, 1995; Lind, 2009), som styrkes af den konstante konfrontation med etiske problemstillinger i hverdagen. Det innovative aspekt i dette træningsprogram, som der kan læses mere detaljeret om i denne rapport, der er udgivet på WADAs hjemmeside (Elbe $\&$ Brand, 2013), er at programmet er orienteret mod at indikere for atleten, at hverken viden, etik eller regler vil fritage en atlet fra at tage hans/hendes egne "rigtige" beslutninger. Så i løbet af dette træningsforløb bliver atleter konfronteret med meget udfordrende scenarier, scenarier hvor de endda måske vil tage en beslutning, der involverer at tage ulovlige præparater. Disse beslutninger, som måske involverer afvigende adfærd, bliver ikke rettet, da meningen med disse er at vise atleten, hvor svære nogle situationer kan være. Den underliggende antagelse i programmet er at atleter, gennem at blive konfronteret med disse scenarier, bliver mindet om sportens etos og 


\section{Sport and Exercise Psychology}

efter en overvejende fase muligvis vil huske at overholde den. I programmet indtages der med vilje ikke en højmoralsk position, og der forsøges heller ikke at influere atleterne til at beslutte på en bestemt måde. Programmets design indikerer yderligere, at man tror på atleterne og ikke $ø n s k e r$ at behandle dem formynderisk. Det antages, at ved at designe programmet på denne måde, i stedet for at foreskrive hvad der er "forkert" og "rigtig" adfærd, så kan man indgyde selvtillid, fremme selvbestemmelse, styrke eksisterende ressourcer og motivere atleter til at holde sig fra doping.

\section{Deltagere, intervention, undersøgelsesdesign}

Niogtres unge eliteatleter (34 mænd, 35 kvinder; 15.5 \pm 2.4 år gamle) blev udvalgt til at deltage i vores første forsøg på empirisk at evaluere denne træningseffekt. Undersøgelsen blev udført i et kontrolleret præ- og posttest design (tougers interval). Deltagerne blev tilfældigt fordelt til enten en etisk beslutningstagen træningsgruppe eller til en sammenligningsgruppe, hvor et standard anti-doping undervisningsprogram blev gennemført (vidensbaseret tilgang). Deltagerne i ikke-interventions kontrolgruppen blev rekrutteret separat og blev ikke allokeret tilfældigt. Træning og måling af de afhængige variable blev foretaget $i$ et fuldt automatiseret online set-up. Deltagerne påbegyndte undersøgelsen ved (1) at logge ind i prætesten, (2) udfylde erklæringen for informeret samtykke og (3) færdiggøre testen der måler den afhængige variabel. I trin (4) blev deltagerne tilfældigt tildelt et af de to eksperimentelle betingelser: etisk træning (ET) eller videnstræning (Knowledge Training; KT). Den etiske træning indebar seks sessioner med tre dilemmaer i hver. Alle dilemmaer omhandlede fiktive unge atleter, der var $\mathrm{i}$ begyndelsen af deres karriere. Hver af de seks træningssessioner indeholdte et dilemma, der havde fokus på en kvindelig atlet, et med fokus på en mandlig atlet og et med fokus på en socialgruppe (f.eks. hold, atlet og træner, atlet og forældre, atlet og fysioterapeut, etc.). De 18 dilemmaer var ens i omfang (5-10 sætninger). Et eksempel på et dilemma og et screenshot er præsenteret $\mathrm{i}$ Figur 1. Hver session indebar opgaver af forskellige sværhedsgrader for at motivere til vedvarende opmærksomhed. Opaverne, hvilke var inkluderet i hver individuel session, var 1) læse dilemmaet; 2) tage en beslutning; 3) skabe individuelle argumenter; og 4) rangordne dem i forhold til egne præferencer. Der var en progression i de seks træningssessioner i forhold til (a) stigende sværhedsgrad i opgaver (b) stigende kompleksitet i argumenter og (c) stigende densitet af svære opgaver. Den vidensbaserede tilgang, som også bestod af seks træningssessioner, indeholdte seks forskellige dele, der hver var opdelt i to underkategorier: (1) introduktion (kendte dopingtilfælde og ofte stillede spørgsmål vedrørende doping), (2) forstadier til og konsekvenser af doping, (3) forbudte præparater og metoder, (4) dopingkontrolsystemet (introduktion til kontrolsystemet og procedurer for dopingkontrol), (5) lov, pligt og straf (lov og straf samt personlige rettigheder og pligter) og (6) antidoping på internettet (NADO online og andre anti-doping sider). Strukturen og indholdet i denne træning var baseret på det tyske NADO's High-Five Program (NADA, 2010). For at opfordre til læsning og bearbejdning af informationen, blev der udført korte vidensøvelser i slutningen af hver underkategori.

Separat fra denne undersøgelse blev effekten af endnu en kombineret træningsgruppe (CT) undersøgt. Denne gruppe fik en kombination af ET og KT. Denne kombinerede træning (præ-test, seks træningssessioner, post-test) bestod af Træningssession 1 fra videnstræning
(KT-1; Introduktion til doping), efterfulgt af Session 1 som præsenteret til den etiske træningsgruppe (ET-1; 3 dilemmaer), som blev efterfulgt af KT-sessionen om forbudte præparater og metoder, ET Session 2 (3 dilemmaer), KT-sessionen om ideen bag og procedurerne for dopingkontrolsystemet og en afsluttende session om etisk beslutningstagen træning (ET-3; 3 dilemmaer). Alle andre aspekter af træningen var identisk med træningerne beskrevet i de foregående afsnit.

Hovedvariablen, anvendt til at vurdere effekten af træningsprogrammerne i disse undersøgelser, var en forkortet version af Performance Enhancement Attitude Scale (PEAS; Petrozci \& Aidman, 2009). Holdninger, som har vist sig at være den stærkeste indikator på intentionen om at tage doping (Tsorbatzoudis, 2009), synes at afspejle udbredelsen af doping bedre end resultater fra dopingkontroller (Striegel, Ulrich \& Simon, 2010). I denne undersøgelses stikprøve var gennemsnitsscoren af denne 6 -item PEAS version, før interventionen, $8.77(S D=3.68)$, hvor den teoretiske skala går fra 6 til 36. Jo højere score, desto mere positiv var atletens indstilling til doping. Den interne konsistens af denne forkortede skala var $a=.70$.

\section{Resultater}

Forud for, og også efter interventionen, var den gennemsnitlige holdning til doping hos de unge atleter lav til meget lav, hvilket indikerer at doping blev vurderet negativt i alle grupper ( $E T, K T, C G$ og $C T$ ). En multivariat variansanalyse (MANOVA) viste en signifikant omnibus effekt. Post-hoc kontrast analyser viste en signifikant, men dog marginal forøgelse (+2.6 score i gennemsnit) i indstillingen til doping blandt deltagere $\mathrm{i}$ den etiske træningsgruppe (ET), sammenlignet med kontrolgruppen (CG). Alle andre kontraster viste insignifikante resultater. Dette understøtter, at en interventionseffekt ikke blev opnået i hverken den vidensbaserede træningsgruppe (KT), i kontrolgruppen (CG) eller i den kombinerede træningsgruppe (CT).

\section{Diskussion}

Projektets resultater var i uoverensstemmelse med antagelsen om, at træningen i etisk beslutningstagen ville mindske positive indstillinger til doping. I stedet viste undersøgelsen en betydelig effekt i den modsatte retning, med andre ord - en uventet forøgelse i PEAS' dopingindstillingsscore. Ingen signifikante resultater viste sig i de andre grupper, dvs. PEAS scorer forblev uændret hos atleter, der deltog enten i det almindelige undervisningsprogram, $\mathrm{i}$ den kombinerede træning eller $\mathrm{i}$ kontrolgruppen. Det er dog vigtigt at bemærke, at på trods af de øgede PEAS værdier $\mathrm{i}$ etisk beslutningstagen træningsgruppen, så er disse værdier stadig meget lave og indikerer, at deltagerne på det kraftigste tager afstand fra doping, dvs. en klar anti-doping holdning.

Baseret på disse resultater kan det tolkes, at atleternes stereotype måde at svare på (kun) har ændret sig i gruppen; etisk beslutningstagen. En forklaring på dette er, at gennem beslutningstagen træningen, med doping relaterede dilemmasituationer, er atleterne blevet bevidste om, at doping ikke er et klart "ja" eller "nej" emne. De er blevet bevidste om, at mange faktorer influerer ens for eller imod beslutninger, når virkeligheden bliver mere kompleks. I lyset af denne tolkning viser resultaterne også, at atleterne har udviklet deres egne holdninger yderligere, ved at sætte spørgsmålstegn ved gyldigheden af deres tidligere overbevisninger. Dette er hovedsageligt understøttet af standardiserede interviews, som vi har 


\section{Sport and Exercise Psychology}

gennemført med nogle af deltagerne efter træningen var færdiggjort. En deltager udtalte: "Jeg skulle tænke over tingene og finde mit eget svar i forhold til doping... Jeg kunne godt lide, at jeg selv skulle tage stilling til, hvad der var godt og skidt og at jeg skulle udtrykke det i mine egne ord... plus, jeg skulle ikke acceptere nogen andres holdning, jeg skulle beslutte det selv. Nu har jeg min egen holdning til doping." Denne udtagelse kan tolkes som et eksempel på, at atleterne, efter at have færdiggjort den etiske beslutningstagen træning, er bedre forberedt hvis/når de møder en virkelig dilemmasituation.

Den kombinerede træning, som inkluderede tre etiske træningssessioner viste ingen effekt. Det kan antages, at antallet af sessioner var for lavt til at opnå en effekt. Afslutningsvis kan det siges, at denne undersøgelse er den første empiriske undersøgelse af effekten af en dopingrelateret etisk beslutningstagen træning med en stikprøve af unge eliteatleter, som på sin vis stadig tager form som en pilotundersøgelse.

Praktiske Implikationer og Anvisninger for Videre Forskning

Resultaterne fra vores første anvendelse af dette etisk beslutningstagen træningsprogram giver mulighed for at videregive praktiske anbefalinger og foreslå ideer til fremtidig forskning. Et overraskende aspekt i forhold til resultaterne er, at de er dannet på baggrund af et træningsprogram, der udelukkende blev gennemført online. Online træninger er ikke optimale læringsmiljøer. I denne ramme har deltagere ikke mulighed for at interagere med en underviser (eller f.eks. andre deltagere) og alle informationer, opgaver og instruktioner er præsenteret skriftligt. Dette kræver en stor grad af selvkontrol og disciplineret selvstudie af deltagerne; alle kompetencer må erhverves på egen hånd. På den anden side kan det siges, at et online læringsværktøj er meget praktisk for atleter, da de kan få adgang til det fra hvor som helst og på ethvert tidspunkt, som passer godt ind i deres travle kalender. Fremtidig forskning burde derfor undersøge, hvorvidt effekten af træningen ville ændre sig, hvis online træning blev suppleret med interaktioner med en underviser eller coach. Angående det har vi udviklet en træningshåndbog til undervisere og coaches som inkluderer øvelser og eksempler i klasserum og praksisbaseret træning i elitesport (Brand, Berding, Schlegel, \& Elbe, 2012). Denne manual er på nuværende tidspunkt kun tilgængelig på tysk, men kunne nemt oversættes til flere sprog, så den vil blive tilgængelig for en større population af undervisere og coaches.

Yderligere kunne den etisk beslutningstagen træning integreres $\mathrm{i}$ allerede eksisterende forebyggende initiativer og kampagner fra nationale anti-doping organisationer. De etiske dilemmaer og relaterede øvelser er for nuværende tilgængelige på tysk og engelsk; en græsk og en hollandsk version er ved at blive udarbejdet. En fordel ved at oversætte til flere sprog er, at yderligere empiriske tests af træningsprogrammets effektivitet vil kunne udføres. Yderlige kan tilføjes, at den udarbejdede håndbog (Brand et al., 2012) bidrager med mange eksempler på aktiviteter og øvelser, som nemt kan integreres i atletens daglige træning. Den kan også danne et solidt grundlag, hvorfra undervisere og coaches kan videreuddannes.

Det beskrevede program repræsenterer et alternativt koncept for forebyggende dopinginterventioner.
Resultaterne fra den empiriske undersøgelse skal tolkes med forsigtighed. Der er flere begrænsninger, for eksempel i forhold til den valgte stikprøvestørrelse og diversitet i stikprøven. Alligevel tror vi på, at træningsprogrammet $\mathrm{i}$ sig selv er et skridt i den rigtige retning; det har i det mindste potentialet til at inspirere fremtidige uddannelsesmæssige anti-doping interventioner. Vi opfordrer derfor til gentagelser af denne præliminære effektundersøgelse, der benytter større og mere forskelligartede stikprøver. I fremtidig forskning kunne det også undersøges, hvorvidt effekter kan opnås ved kortere eller færre træningssessioner, da interventionen kræver en del af atletens begrænsede fritid (seks sessioner af cirka 30 minutter). En generel begrænsning, ikke kun i forhold til undersøgelsen beskrevet ovenfor, er at et direkte mål for indstillingen til doping blev inkluderet. På den anden side kan selvrapporterende spørgeskemaer indeholde den ulempe at være påvirket af strategiske svar. Vi anbefaler fremtidige studier at medinkludere indirekte målinger og implicitte holdninger (Brand, Heck, \& Ziegler, 2014; Brand, Wolff, \& Thieme, 2014; Petroczi et al., 2008; Petroczi, Uvacsek, Nepusz, Deshmukh, Shah, Aidman, et al., 2011) og eksempelvis, benytte objektive kriterier til udvælgelse af deltagere med et mere udtalt behov for forebyggelse (Musshoff, Driever, Lachenmeier, Lachenmeier, \& Banger, 2006). Afslutningsvis, anbefaler vi at inkludere en opfølgningsundersøgelse af mellem og langsigtede træningseffekter, eksempelvis efter seks måneder eller et år.

\section{Konklusion}

Etisk beslutningstagen træning er en ny form af uddannende tilgang til at forebygge doping. Til sammenligning med de udbredte vidensbaserede antidoping uddannelsesprogrammer, er den ikke formynderisk overfor atleter ved at definere, hvad rigtig og forkert dopingrelateret adfærd er. I stedet placeres atleter, i dette træningsprogram, i en situation hvor de er nødsaget til at træffe og begrunde deres egne beslutninger baseret på deres eget moralske ræsonnement. Deres beslutninger bliver ikke bedømt. Ved at designe programmet på denne måde, skabes der rum for, at atleternes individuelle moralske ressourcer kan styrkes. Gennem dette kapitel blev relevansen af moralsk ræsonnement for anti-doping forebyggelse forklaret, og det blev demonstreret hvordan træning af etiske kompetencer kan implementeres i en uddannende anti-doping tilgang samt hvordan det kan anvendes i praksis. Som beskrevet, så er vores træningsprogram stadig nyt. Det er vores håb, at fremtidige undersøgelser vil kunne undersøge effekten af dette træningskoncept yderligere og viderebygge på vores første empiriske resultater.

Vores forslag er altså ikke, at nedlægge allerede etablerede programmer, der har fokus på at udbrede viden om doping, men derimod at supplere dem med reel træning af kompetencer. Dette kapitel giver et eksempel på, hvordan moral og en specifik relateret kompetence (etisk ræsonnement) kan trænes. Fremtidig forskning bør vise hvordan denne træning kan anvendes til at forbedre eksisterende programmer samt hvordan det kan bidrage til en holdbar succes for forebyggende programmer. 
Ajzen, I. (1991). The theory of planned behaviour. Organizational Behaviour \& Human Decision Processes, 50, 179-211.

Alderson, J., \& Crutchley, D. (1990). Physical education \& the national curriculum. In N. Armstrong (ed), New Directions in Physical Education (pp. 37-62). Champaign, IL: Human Kinetics.

Backhouse, S., McKenna, J., \& Patterson, L. (2009). Prevention through education: A review of current international social science literature. Montreal, Canada: World Anti Doping Agency.

Barry, V. (1979). Moral issues in business. Belmont, CA: Wadsworth.

Blatt, M. M. (1969). The effects of classroom discussion upon children's level of moral reasoning (unpublished doctoral dissertation). University of Chicago.

Blatt, M. M., \& Kohlberg, L. (1975). The effect of classroom moral discussion upon children's level of moral judgment. Journal of Moral Education, 4, 129161.

Bockrath, F., \& Franke, E. (1995). Is there any value in sports? About the ethical significance of sport activities. International Review for the Sociology of Sport, 30(3-4), 283-310.

Brand, R., Berding, A., Schlegel, M., \& Elbe, A.-M. (2012). Doping - Soll ich oder soll ich nicht?

EthiktrainingfürSportler, Trainer und Lehrer [Doping - Should I or shouldn't I? Ethical training for athletes, coaches, and teachers]. Stuttgart: NeuerSportverlag.

Brand, R., Heck, P., \& Ziegler, M. (2014). Illegal performance enhancing drugs and doping in sport: a picture-based brief implicit association test for measuring athletes' attitudes. Substance Abuse Treatment, Prevention, and Policy, 9:7. doi: 10.1186/1747-597X-9-7

Brand, R., Wolff, W., \& Thieme, D. (2014). Using response-time latencies to measure athletes' doping attitudes: the brief implicit attitude test identifies substance abuse in bodybuilders. Substance Abuse Treatment, Prevention, and Policy, 9:36. doi: 10.1186/1747-597X-9-36

Bredemeier, B. J., \& Shields, D. L. (1984). Divergence in moral reasoning about sport and life. Sociology of Sport J ournal, 1, 348-357.

Connor, J., Mazanov, J., \& Woolf, J. (2013). Would they dope? Revisiting the Goldman dilemma. British J ournal of Sports Medicine, 47(11), 697 - 700,

Elbe, A.-M. \& Brand, R. (2013). Being a fair sportsman: Ethical decision making as a chance for doping prevention? Final Report for the World Anti Doping Agency Social Science Research Grant (2008-2011). Retrieved from: http://www.wada-ama.org/ Documents/

Education_Awareness/SocialScienceResearch/Funde d_Research_Projects/2008/ELBE\% 20$\% 20 \% 282008 \% 29 \% 20$ Final_report.pdf

Elbe, A.-M. \& Brand, R.(2016). The effect of an ethical decision-making training on young athletes' attitudes towards doping. Ethics \& Behavior, 26, 3244.Elbe, A.-M., Overbye, M., Knudsen, M. \& Pfister, G. (2014). Danish elite athletes' perceptions of antidoping deterrents. Proceedings of the SFPS' 5 th International Congress of Sport Psychology (p. 78). Université de Nice Sophia Antipolis.
Franke, E. (1978). Theorie und Bedeutung sportlicher Handlungen. Voraussetzungen und Möglichkeiten einer Sporttheorie aus handlungstheoretischer Sicht [TheoryandmeaningofsportactionsConditionsandpossibilitiesof a sporttheoryfromand action-theoreticalperspective]. Schorndorf: Hofmann.

Franke, E. (1988). Ethische Aspekte des Leistungssports [Ethicalaspectsof high-performance sport]. Clausthal-Zellerfeld: Deutsche Vereinigung für Sportwissenschaft.

Gandz, J., \& Hayes, N. (1988).Teaching business ethics.J ournal of Business Ethics, 7, 657-669.

Goldberg, L., MacKinnon, D. P., Elliot, D., Moe, E., Clarke, G., \& Cheong, J. (2000). The adolescents training and learning to avoid steroids program: Preventing drug use and promoting health behaviors. Archives of Pediatric and Adolescent Medicine, 154, 332-338.

Goldman, B., Bush, P. J., \& Klatz, R. (1984). Death in the locker room: Steroids \& sports. South Bend, Ind: I carus Press.

Hanson, J. M. (2009). Equipping athletes to make informed decisions about performance-enhancing drug use: A constructivist perspective from educational psychology. Sport in Society, 12,394410.

Haugen, K. K. (2004). The performance-enhancing drug game. Journal of Sports Economics,5(5), 67-86.

Hemphill, D. (2009). Performance enhancement and drug control in sport: Ethical considerations. Sport in Society, 12(3), 313-326.

Houlihan, B. (2002). Managing compliance in international anti-doping policy: The world anti-doping code. European Sport Management Quarterly, 2, 188-208.

Kavussanu, M. \& Ntoumanis, N. (2003). Participation in sport and moral functioning: Does ego orientation mediate their relationship? Journal of Sport \& Exercise Psychology, 25(4), 1-18.

Kohlberg, L. (1964). Development of moral character and moral ideology. In M. L. Hoffman \& L. W. Hoffman (Eds.), Review of child development research, (pp. 381-431). New York: Russel Sage Foundation.

Kuchler, W. (1969). Sportethos. Eine moraltheologische Untersuchung des im Lebensbereich Sport lebendigen Ethos als Beitrag zu einer Phänomenologie der Ethosformen [Sportethos. A moral-theological investigation of the Ethos alive in sport as a contribution to a phenomenology of Ethos forms]. München: Barth.

Laure, P., \& Lecerf, T. (1999). Prevention of doping in sport in adolescents: Evaluation of a health education based intervention. Archive Pediatrics, 6 , 848-854.

Laure, P., \& Lecerf, T. (2002). Doping prevention among young athletes: Comparison of a health educationbased intervention versus information-based intervention. Science and Sports, 17, 198-201.

Lerkiatbundit, S., Utaipan, P., Laohawiriyanon, C., \& Teo, A. (2006). Randomized controlled study of the impact of the Konstanz method of dilemma discussion on moral judgment. Journal of Allied Health, 35, 101-108.

Lind, G. (2009). Moral ist lehrbar. Handbuch zur Theorie und Praxis moralischer und demokratischer Bildung [Morality can be taught. Handbook on theory and 
practice of moral and democratic education]. München, Germany: Oldenbourg.

Long, T., Pantaléon, N., Bruant, G., \& d'ArripeLongueville, F. (2006). A qualitative study of moral reasoning of young elite athletes. The Sport Psychologist, 20, 330-347.

Louveau, C., Augustini, M., Duret, P., Irlinger, P., \&Marcellini, A. (1995). Dopage et performance sportive. Analyse d'une pratique prohibee [Doping and Sports. Analysis of a prohibited practice]. Paris: I NSEP-Publications.

McFee, G. (1998). Are there philosophical issues in respect of sport (other than ethical ones)? In M. J. McNamee \& S. J. Parry (Eds.), Ethics and sport (pp. 3-18). London: Routledge.

Morgan, W. J. (2007). Ethics in Sport. Champaign, Illinois: Human Kinetics.

Musshoff, F., Driever, F., Lachenmeier, K., Lachenmeier, D. W., \& Banger, M. (2006). Results of hair analyses for drugs of abuse and comparison with self-reports and urine tests. Forensic Science International, 156(2-3), 118-123.

NADA (2010). High Five. Gemeinsam Gegen Doping - Ein Ratgeber für junge Sportlerinnen und Sportler [ High Five. Together against doping. A guide for young athletes]. Bonn, Germany: NADA.

Ommundsen, Y., Roberts, G. C., Lemyre, P. N., \& Treasure, D. (2003). Perceived motivational climate in male youth soccer: Relations to social-moral functioning, sportspersonship and team norm perceptions. Psychology of Sport \& Exercise, 25, 397-413.

Overbye, M., Elbe, A.-M., Knudsen, M., \& Pfister, G. (2014). Athletes' perceptions of anti-doping sanctions: The ban from sport vs. social, financial and self-imposed sanctions. Manuscript submitted for publication.

Pawlenka, C. (2004). Sportethik. Regeln - Fairneß Doping [Sport ethic. Rules - fairness - doping]. Paderborn: Mentis.

Petroczi, A., \& Aidman, E. V. (2009). Measuring explicit attitude toward doping: Review of the psychometric properties of the Performance Enhancement Attitude Scale. Psychology of Sport and Exercise, 10, 390396.

Petroczi, A., \& Naughton, D. P. (2011). Impact of multidisciplinary research on advancing anti-doping efforts. International J ournal of Sport Policy, 3, 235259.

Petroczi, A., Aidman, E. V., \& Nepusz, T. (2008). Capturing doping attitudes by self-report declarations and implicit assessment: A methodology study.Substance Abuse Treatment, Prevention, and Policy, 3(9), 1-12.

Petroczi, A., Uvacsek, M., Nepusz, T., Deshmukh, N., Shah, I., Aidman, E. V., Barker, J., Tóth, M., \& Naughton, D. P. (2011). Incongruence in doping related attitudes, belief and opinions in the context of disconcordant behavioural data: In which measures do we trust? PloS One, 6(4),1-10.

Piaget, J. (1932). The Moral Judgment of the Child. London: Kegan Paul, Trench, Trubner and Co.

Pilz, G. A. (1995). Performance sport: Education in fair play? International Review for the Sociology of Sport, 30(3-4), 391-418.

Schneider, A. J., \& Butcher, R. B. (2000). A philosophical overview of the arguments on banning doping in sport. In T. Tännsjö\& C. M. Tamburrini (Eds.), Values in Sport: Elitism, Nationalism, Gender
Equality and the Scientific Manufacture of Winners (pp. 185-99). London: E \& FN Spon.

Siedentop, D., Hastie, P., \& van der Mars, H. (2004). Complete guide to sport education. Champaign, IL: Human Kinetics.

Singler, A. (2011). Dopingprävention - Anspruch und Wirklichkeit [Doping prevention - Claims and reality]. Aachen, Germany: Shaker Verlag.

Singler, A., \& Treutlein, G. (2010). Doping - von der Analyse zur Prävention [Doping - From analysis to prevention]. Aachen, Germany: Meyer \& Meyer.

Steenbergen, J., \& Tamboer, J. W. I. (1998). Ethics and the double character of sport: An attempt to systematize the discussion on the ethics of sport. In M. J. McNamee \& S. J. Parry (Eds.), Ethics and sport, (pp. 35-53). London: Routledge.

Striegel, H., Ulrich, R., \& Simon, P. (2010). Randomized response estimates for doping and illicit drug use in elite athletes. Drug and Alcohol Dependence, 106(23), 230-232.

Trout, G. J., \& Kazlauskas, R. (2004). Sports drug testing - An analyst's perspective. Chemical Society Reviews, 33, 1-13.

Tsorbatzoudis, H. (2009). Determinants of Doping Intentions in Sport. Montreal, Canada: World Anti Doping Agency.

Volkwein, K. A. (1995). Ethics and top-level sport - A paradox? International Review for the Sociology of Sport, 30(3-4), s. 311-321.

WADA (2009). World-Anti-Doping-Code. Montreal, Canada: WADA.

Wright, M. (1995). Can moral judgment and ethical behavior be learned? A review of the literature. Management Decision,33(10), 17-28. 